\title{
Testing the Limits of the EC Treaty Article on Non- discrimination
}

\author{
LISA WADDINGTON*
}

\begin{abstract}
Article 13 EC, the new general non-discrimination article, gives the Community the competence to adopt measures to combat discrimination on the grounds of sex, racial or ethnic origin, religion or belief, disability, age or sexual orientation. In this paper the likely impact of the new provision is considered. The potential for the adoption of instruments based on Article 13, as well as the Article's possible effect on legislation and policy based on other Treaty articles and the case law of the Court of Justice is examined. It is argued that Article 13 is not only likely to prompt Commission proposals for concrete non-discrimination measures but also, perhaps more significantly, exert more subtle influences on Community policy by, for example, allowing greater scope for the inclusion of equal opportunity clauses and 'mainstreaming' in Community instruments, and encouraging an expansion of the general principle of equality recognised by the Court.
\end{abstract}

\section{INTRODUCTION}

Since the signing of the Treaty on European Union in Maastricht in 1992, calls have gradually been increasing for a greater recognition of, and firmer foundation for, fundamental (social) rights within the European Union. These calls naturally became louder following the Opinion of the European Court of Justice excluding the possibility of EC accession to the European Convention of Human Rights ${ }^{1}$ and during the lead up to the Amsterdam Intergovernmental Conference. Academics, ${ }^{2}$ independent EU advisory committees, ${ }^{3}$ groups repre-

* Lecturer in European Community Law, Maastricht University (NL). This paper was presented at the Conference 'Grant, Marschall and Beyond' organised by the Centre for European Studies, University of Cambridge on 28 November 1998. A longer version of this paper will be published in the Cambridge Yearbook of European Legal Studies (Hart, 1999). I am grateful to Mark Bell and Bruno de Witte who commented on an earlier version of this paper. This article was completed in February 1999 and it was not possible to include information on developments occuring after this date. Responsibilities for any errors or emissions naturally rest with the author.

${ }^{1}$ Opinion 2/94 concerning accession by the Community to the European Convention for the Protection of Human Rights and Fundamental Freedoms [1996] ECR I-1759.

2 See, for example, Lammy Betten and Delma MacDevitt (eds), The Protection of Fundamental Social Rights in the European Union (Kluwer, 1996).

${ }^{3}$ See, for example, For a Europe of Civic and Social Rights, Report of Comité des Sages, (European Commission, 1996). 
senting the interests of EU citizens and residents, and the European Parliament ${ }^{4}$ lamented the almost complete absence of fundamental social rights in the Treaty, and called for an ambitious revision of the Treaty. To a large extent these calls went unheard in Amsterdam, and the new Treaty does not incorporate a comprehensive list of social fundamental rights. However, the new Treaty does include at least one important provision which will enhance the Community's ability to protect and promote fundamental rights: the general nondiscrimination provision contained in Article 13 EC. ${ }^{5}$ Prior to Amsterdam the Treaty only addressed discrimination against individuals on the grounds of nationality (Article $12 \mathrm{EC}$, ex Article $6 \mathrm{EC}$ ), ${ }^{6}$ and in the limited area of equal pay for equal work for men and women (Article 141 EC, ex Article 119 EC). ${ }^{7}$ Article 13 is far broader, in that it covers discrimination on the grounds of sex, racial or ethnic origin, religion or belief, disability, age or sexual orientation. Furthermore, unlike Articles 12 and 141, Article 13's inclusion in the Treaty was not primarily prompted by the desire to combat discrimination for economic reasons or to complement the single market. Instead it is part of a trend which is arguably presently reflected more in rhetoric than in reality: to bring Europe 'closer to the citizens'. ${ }^{8}$ The purpose of this paper is to consider the possible impact of the new non-discrimination provision. The paper begins with a detailed examination of the field of application of the Article 13. An analysis will then be conducted of the likely impact of the Article, including its possible effect on legislation and policy which finds their legal base in other articles in the Treaty, and on the case law of the European Court of Justice. ${ }^{9}$

\footnotetext{
${ }^{4}$ The European Parliament's 1995 Resolution on the IGC called for 'an explicit reference in the Treaty to the principle of equal treatment irrespective of race, sex, age, handicap or religion' ([1995] OJ C 151/56, 17.5.95).

5 The provision was initially numbered 6a following the numbering of EC Treaty as used in the body of the Amsterdam Treaty. It is now commonly referred to as Article 13, in accordance with the renumbering of the Treaty which followed the Amsterdam revision.

${ }^{6}$ As noted above, the Amsterdam Treaty has resulted in a re-numbering of the Treaty on European Union. In this paper the renumbered articles will be referred to. Reference will also be made to the earlier numbering (which applies to the Treaty which is in force pending ratification of the Amsterdam Treaty).

${ }^{7}$ In addition a number of directives have been adopted on the basis of Articles 100, 100a, 235 and the Agreement on Social Policy annexed to the Treaty on European Union. These directives deal primarily with equal treatment for men and women in the fields of employment and social security.

${ }^{8}$ See, for example, the Commission Report of 10 May 1995 on the Operation of the Treaty on European Union which identifies as one of the 'major challenges for Europe' 'to make Europe the business of every citizen', included in White Paper on the 1996 Intergovernmental Conference, Volume 1, Official Texts of the European Union Institutions, (European Parliament, 1996).

${ }^{9}$ For information on the background to Article 13, and the developments which led to its incorporation in the Amsterdam Treaty, see M. Bell and L. Waddington, 'The 1996 Intergovernmental Conference and the Prospects of a Non-discrimination Treaty Article', (1996) ILJ 25, $320-36$.
} 


\title{
2. THE FIELD OF APPLICATION OF ARTICLE 13
}

\begin{abstract}
Without prejudice to the other provisions of this Treaty and within the limits of the powers conferred by it upon the Community, the Council, acting unanimously on a proposal from the Commission and after consulting the European Parliament, may take appropriate action to combat discrimination based on sex, racial or ethnic origin, religion or belief, disability, age or sexual orientation.
\end{abstract}

In order to determine the field of application of Article 13 it is necessary to examine the wording of the provision. Article 13 contains some unusual phrases, the precise meaning of which is not immediately clear.

\section{A. 'Without prejudice to the other provisions of this Treaty'}

This initial phrase in Article 13 is not unusual, in that it can be found in numerous other provisions of the existing Treaty. ${ }^{10}$ However, the phrase is unusual when compared to the long-standing non-discrimination provision found in Article 12 (ex Article 6). This Article instead contains the term 'without prejudice to any special provision contained [in this Treaty]' (italics added). The Court has held that this latter phrase refers to: 'Other provisions of the Treaty in which the application of the general principles set out in that article is given concrete form in respect of specific situations. Examples of that are the provision concerning free movement of workers, the rights of establishment and the freedom to provide services. ${ }^{11}$ This means that Article 12 cannot constrain or detract from the use or scope of other Treaty provisions which provide for specific means of prohibiting discrimination on the grounds of nationality.

It is unclear whether the term found in Article 13, with its reference to 'other' rather than 'special' provisions of the Treaty, should be interpreted in the same way. At least two factors suggest that this should not be the case: the original draft of Article 13, prepared under the Irish Presidency, was modelled, at least in this respect, on Article 12. However, the reference to 'special provisions' was removed by the Dutch Presidency, whose draft resulted in the adopted text.

${ }^{10} \mathrm{Cf}$, for example, Article 10 EC (ex Article 5)-Member State obligations; Article 14 (ex Article 7a) - general provisions/internal market; Article 22 (ex Article 8e) - citizenship; Article 137 (ex Article 118)-social provisions; Article 179 (ex Article 130w)-development cooperation; Article 280 (ex Article 209a) - financial provisions.

${ }_{11}$ Case C-186/87 Cowan v Trésor Public [1989] ECR 195, para 14, cited by Mark Bell, 'The New Article 13 EC: a Sound Basis for EU Anti-discrimination Law?' (1999) 6 Maastricht Journal of European and Comparative Law, 5-24. 
Secondly, this distinction between 'other' and 'special' provisions can also be found in other language versions of the Treaty. ${ }^{12}$

If the phrase found in Article 13 means something other than the interpretation given to the related term in Article 12, it is not clear what that could be. Perhaps the reference to 'special provisions' means that only those provisions which can be used to contribute to achieving the set objective are to take precedence when a legal basis choice is made, whilst the phrase 'other' provisions emphasizes that all other provisions of the Treaty are to take precedence where there is a possible conflict. If so, the former allows for greater protection of the target group if this is provided elsewhere in the Treaty, whilst the latter allows for lesser protection if provided for elsewhere in the Treaty. However, it is difficult to see how this approach to Article 13 would work in practice, or to understand how a provision contained in 'Part One: Principles' of the Treaty could be undermined in this way.

An alternative explanation may be that the phrase 'other provisions' refers to those provisions of the Treaty which do not specifically pursue a nondiscriminatory objective, but which cover areas in which discrimination on the grounds mentioned in Article 13 is relevant. Prime examples are provisions in the Title on Social Policy which refer to, inter alia, the working environment, working conditions, information and consultation of workers, education and vocational training. Since Article 13 is 'without prejudice' to such provisions it is possible to include non-discrimination clauses in secondary legislation adopted on the basis of these provisions, and so ensure that the specific policies/ instruments are applied in a non-discriminatory manner.

\section{B. 'Within the limits of the powers conferred by it [the Treaty] upon the Community'}

Again this term is not unique in the Treaty, and indeed it is found in a number of other provisions in Part One of the Treaty..$^{13}$ However, the non-discrimination provision in Article 12 makes use of an alternative phrase: 'Within the scope of the application of this Treaty.' This latter phrase was also included in the original draft of Article 13, but was removed and replaced under the Dutch Presidency. The difference in wording, and the rejection of the original proposal, again leads one to conclude that the field of application of these two articles is different. However, no guidance is given as to whether the phrase contained in Article 13 allows for greater or lesser intervention than that

\footnotetext{
${ }^{12}$ French: 'dispositions particulières' (Article 12) and 'autres dispositions' (Article 13); German: 'besonderer Bestimmungen' and 'sonstigen Bestimmungen'; Italian: 'disposizioni particolari' and 'altre disposizioni'; Dutch: 'bijzondere bepalingen' and 'andere bepalingen'.

${ }_{13} \mathrm{Cf}$, Articles 5, 7, 8, and 9 (ex Article 3b, 4, 4a and 4b).
} 
provided for under Article 12. This turns on the interpretation of the concept of 'powers' conferred by the Treaty.

Bell has convincingly argued, on the basis of an examination of other provisions of the Treaty, the Court's case law and non-English versions of Article 13, that the terms 'powers' should be interpreted to mean 'competence'. ${ }^{14} \mathrm{He}$ notes, in particular, that some non-English versions of Article 13 make express use of the term 'competences' rather than 'powers'. Furthermore, the Court has at times made a distinction between the 'scope' of the Treaty and the 'competences' of the Community, ${ }^{15}$ suggesting that the former concept is broader. Bell concludes that: 'The implication is that Article 13 may only be relied upon to prohibit discrimination within those areas for which the Community already has competences,' and argues that this means that the field of application of Article 13 is 'if anything ... slightly less broad ... than Article 12'. This suggests that Article 13 can only provide a legal basis for measures to combat discrimination in areas in which the Community already has competence.

\section{C. 'Appropriate action'}

Article 13 allows the Community to take 'appropriate action' to combat discrimination, but does not elaborate on what kind of action will be deemed 'appropriate'. This somewhat vague notion is not found elsewhere in the Treaty. ${ }^{16}$ Given that no measures are expressly excluded, one can assume that the concept embraces all the legal instruments referred to in Article 254 EC (ex Article 191 EC) as well as the numerous other sui generis instruments which the Community regularly makes use of, including action programmes. In practice the requirement that the action be 'appropriate', meaning in the first instance presumably 'appropriate' in the eyes of the Commission, European Parliament, and above all else the Council, will impose a restriction on the kinds of instruments adopted. However, it is interesting to note that the Commission has already committed itself to proposing a Directive to combat racial discrimination on the basis of Article 13 following ratification of the Treaty, showing that this institution, at least, regards binding Community legislation as a form of 'appropriate action' to combat certain kinds of discrimination. ${ }^{17}$

${ }^{14}$ Mark Bell, Maastricht Journal, op cit.

15 Case C-152/82 Forcheri v Belgium [1983] ECR 2323. Cited in Bell, ibid.

16 Article 12 , in contrast, allows for the seemingly more limited possibility of the adoption of 'rules' to prohibit discrimination.

${ }_{17}$ See generally, text attached to notes 21 to 23 below. On the specific proposal for a Directive, 


\section{D. 'Action to combat discrimination'}

It is again uncertain what is covered by the concept of action to 'combat' discrimination. In many respects it would have been more logical to have provided for action to 'prohibit' discrimination or action to 'eliminate' discrimination. The former term is found in Article 12 and in the original (Irish) proposal for Article 13, whilst the latter is found in all major international instruments concerned with the fight against discrimination..$^{18}$

The use of the term 'combat' suggests that Article 13 allows the Community to take active (including pre-emptive?) measures to address discrimination rather than merely adopt formal legal rules prohibiting discriminatory practices. This, combined with the fact that Article 13 seems to allow for the adoption of a broad range of Community instruments, seems to open up the field of application and potential impact of measures adopted on the basis of the Article.

\section{THE LIKELY IMPACT OF ARTICLE 13}

\section{A. The Direct Legislative Impact of Article 13}

\section{(i) Absence of direct effect}

Whilst many of the organisations campaigning for the inclusion of a general non-discrimination article in the Treaty called for the provision to be given direct effect, it quickly became clear that there was no support for this amongst the Member States. Therefore, if Article 13 is to have any 'direct' impact on the national legal orders, it must provide the legal basis for additional Community instruments. The experience with Articles 12 and 141 EC show the far-reaching non-discriminatory impact which a provision with direct effect can have, and the impact of Article 13, in comparison, will be proportionately far less. However, this is not to suggest that Article 13 will not result in important changes at the Community or national level, as noted below.

\footnotetext{
Commissioner Flynn's speech 'Anti-Discrimination - The Way Forward' given at the Conference on Anti-Discrimination, Vienna, 4 December 1998, available at http://europa.eu.int/

${ }_{18} \mathrm{Cf}$, Convention on the Elimination of All Forms of Racial Discrimination and the Convention on the Elimination of All Forms of Discrimination Against Women. This point was made by Aart Hendriks in an unpublished commentary prepared by Hendriks and Waddington on the Irish proposal for the non-discrimination article.
} 


\section{(ii) The adoption of legal instruments on the basis of Article 13}

Procedural requirements. Article 13 stipulates that action can only be taken to combat discrimination on the basis of a unanimous decision by the Council, following consultation with the European Parliament.

The requirement of Council unanimity will, in practice, pose a major hurdle to the adoption of ambitious (legislative or binding) non-discriminatory measures, at least in the short run. (Some) Member States may refuse to support such measures out of concern that a Community instruments would undermine or conflict with national policy, or as a result of worries about financial implications, or indeed because they do not view such measures as an 'appropriate' form of action to combat discrimination.

A further possible limitation to the wide-ranging use of Article 13 is arguably the restricted consultative role given to the European Parliament. The Parliament has a history of pressurizing the other institutions to take ambitious steps to combat discrimination, and the weak legislative status that it has been given under Article 13 means that it will be a less significant player when decisions are taken on the basis of this article.

What kinds of discrimination are likely to be addressed? Reference is made in Article 13 to discrimination on eight different grounds. ${ }^{19}$ However, the Council will not be equally willing to take action to combat discrimination on all of these grounds. In order to assess the impact of Article 13 it is useful to consider the forms of discrimination which are likely to be the focus of measures based on Article 13, and the legal format of these instruments.

Racial or ethnic origin and religion. As early as 1986 the European Parliament, Council and Commission adopted a Joint Declaration against Racism and Xenophobia, ${ }^{20}$ and the 1990 s have seen a notable intensification of Community efforts in this field. In 1995 the Commission issued a Communication on racism, xenophobia and anti-semitism. ${ }^{21}$ This was followed by the European Year Against Racism (1997) which involved considerable publicity and, in the same year, the establishment of a European Monitoring Centre on Racism and Xenophobia in Vienna.22 In 1998 the Commission issued a second Communication, entitled 'An Action Plan Against Racism'. ${ }^{23}$ This last document outlines the Commission's plans for the future, and refers to the use the Commission

${ }^{19}$ It should be noted that the list of forms of discrimination in Article 13 is exhaustive, and no 'catch-all' phrase, such as 'any other ground', is included.

20 OJ C 158 of 25 June 1986.

${ }^{21} \operatorname{COM}(95) 653$ final of 13 December 1995.

${ }_{22}$ Council Regulation (EC) 1035/97 of 2 June 1997, OJ L 151 of 10 June 1997.

${ }^{23} \mathrm{COM}(98) 183$ final of 25 March 1998. 
will make of Article 13 to combat discrimination on racial, ethnic or religious grounds.

Additional more specific information was given in December 1998, at a major conference on non-discrimination and Article 13, held in Vienna. Commissioner Flynn announced that the Commission intends to propose an 'Article 13 nondiscrimination package' as soon as the new Treaty comes into force. The plans for this package have not yet been finalised, but it is clear that the package will contain a proposal dealing specifically with racial discrimination. This 'will go beyond the workplace to also cover other areas such as goods and services, health, education and sport'. At this stage it seems as if discrimination on the grounds of religion and belief will not be covered by this proposal. However, these grounds will fall under the second proposal for a Directive mentioned by Commissioner Flynn in Vienna: namely a 'horizontal' Directive covering employment discrimination. This is discussed in more detail below.

Sex. The existing and new provisions in the Treaty which (already) address equal opportunities for men and women mean that Article 13 will be proportionately less important as a possible legal basis for non-discriminatory measures than it will be for the other grounds referred to therein. It now seems as if sex discrimination will not be covered in the proposal for a 'horizontal' employment Directive mentioned above, and it is submitted that Article 137(1) and Article 141, which now allows for the adoption of measures 'to ensure the application of equal opportunities and equal treatment of men and women in matters of employment and occupation', will provide a more suitable legal basis for employment non-discrimination measures than Article 13. This may explain why, although the Community has a clear commitment to addressing sex discrimination, relatively little attention seems to have been paid by the Commission to any new possibilities opened up by Article 13. Articles 137(1) and 141, however, can provide a legal basis only for measures to combat employment discrimination and, as noted above in the context of race, the Commission sees Article 13 as a suitable basis for legislative measures designed to combat discrimination in a number of other areas, including access to goods and services, health and education. This suggests that the real significance of Article 13, from the point of view of sex discrimination, may be to allow the adoption of directives designed to combat discrimination in areas beyond employment.

Disability. Like race, disability is a topic which has attracted a great deal of attention over the past few years. The Community's involvement in the field of disability dates back as far as 1974 when an action programme to promote the 
vocational rehabilitation of people with disabilities was adopted. ${ }^{24}$ Over the years the Community has initiated a series of other action programmes focusing on disability, and in 1986 the Council adopted a Recommendation on the Employment of Disabled People in the European Community. ${ }^{25}$ In 1996 the Commission and then the Council adopted documents which marked a major change in their thinking on disability. The documents in question, the Commission Communication ${ }^{26}$ and the Council Resolution ${ }^{27}$ on equality of opportunity for people with disabilities, embrace a rights based notion of disability and acknowledge that the major challenge facing people with disabilities is discrimination. The Resolution notes the commitment inter alia of the Council and the Member States to 'the principle of equality of opportunity in the development of comprehensive policies in the field of disability' and 'the principle of avoiding or eliminating any form of negative discrimination on the sole grounds of disability'. It was against this background that disability was included in Article 13. Disability will be one of the grounds covered in the Commission's proposal for a 'horizontal' employment discrimination Directive (see below).

Sexual Orientation. The European Parliament has shown an interest in sexual orientation discrimination for some time. ${ }^{28}$ In 1983 the Parliament's Committee on Social Affairs and Employment adopted a report on sexual orientation discrimination in the workplace which called on the Commission to propose instruments designed to eliminate this phenomenon. ${ }^{29}$ The Social Affairs Commissioner at the time, Iver Richard, was sympathetic, but felt that it was not politically feasible for the Council to legislate against this form of discrimination. The Commission has subsequently taken a number of more modest steps. In recent years the Commission has funded research projects examining the issue of sexual orientation discrimination in the European Union, including a major project carried out by the European Human Rights Foundation. ${ }^{30}$ The Commission has also included a reference to harassment on the grounds of sexual orientation in its Code of Good Practice on Sexual Harassment. ${ }^{31}$ These

${ }^{24}$ Council Resolution of 27 June 1974, OJ C 80/30, 9 July 1974.

${ }_{25}$ Council Recommendation of 24 July 1986 OJ L 225/43, 12 August 1986.

${ }^{26} \operatorname{COM}(96) 406$ final, 30 July 1996.

27 Resolution of 20 December 1996, OJ C 12/1 13 January 1997.

${ }^{28}$ For more detailed background on the involvement of the European Parliament and the other Community institutions in the field of sexual orientation discrimination see Mark Bell, 'Sexual Orientation and Anti-Discrimination Policy' in T. Carver and V. Mottier (eds), The Politics of Sexuality (Routledge, 1998).

${ }^{29}$ EP Doc $1-1358 / 83$.

${ }^{30}$ This resulted in the publication of Waaldijk and Clapham (eds), Homosexuality: A European Community Issue (Martinus Nijhoff, 1993).

31 Annexed to the Commission Recommendation on the dignity of women and men at work, adopted on 27 November 1991, OJ L49/1. 
measures have perhaps predictably failed to satisfy (the majority of) the Members of the European Parliament, and in 1994 a report adopted by the Committee on Internal Affairs and Citizens rights called for equal treatment for homosexuals and lesbians in the European Community. ${ }^{32}$ The relevant Commissioner ${ }^{33}$ again responded by referring to the political impossibility of Community legislative intervention and referred to the absence of a specific legal basis. This latter problem has clearly been removed by Article 13. The Commission intends to include a reference to discrimination on the grounds of sexual orientation in its proposal for a 'horizontal' employment Directive based on Article 13. Other than this, there is little sign that the Commission is planning to propose new initiatives in what is, for many Member States, arguably the most controversial ground referred to in Article 13. Commissioner Flynn, in a meeting with the European Parliament Intergroup on Gay and Lesbian Rights, was notably non-committal in this respect, stating: 'We all know how difficult it can be to get unanimity in what may be ... controversial areas. ${ }^{34}$

A general measure designed to combat discrimination. A second element of the 'non-discrimination package' elaborated on by Commissioner Flynn in Vienna is a proposal for a 'framework Directive [dealing] on a general basis with all grounds of discrimination'. ${ }^{35}$ Whilst the original plan seems to have been for this proposal to cover all eight grounds mentioned in Article 13, this no longer appears to be the intention. It seems that sex and race/ethnic origin discrimination will not be covered in the proposal, which will now only address the remaining five grounds: religion, belief, disability, age and sexual orientation. ${ }^{36}$ It is submitted that this approach will only reinforce the 'hierarchy' that already exists with regard to sex discrimination, create a second 'privileged' category of discrimination in the form of race, which as noted will be the focus of a separate proposal, and relegate the remaining categories to a secondary position.

\section{B. The indirect legislative impact of Article 13}

Prior to the adoption of the Amsterdam Treaty most of the groups/grounds of discrimination now mentioned in Article 13 were not referred to at all in the

32 EP Doc A3-0028/94.

${ }^{33}$ Bruce Millan.

${ }^{34}$ Speech given in Strasbourg, 13 January 1998, available at http://europa.eu.int/.

35 The third element of the package will be an action programme designed to strengthen cooperation with Member States and civil society, with an accent on building partnerships and networking, deepening knowledge and spreading best practice.

${ }^{36}$ This is based on information given out by Commission officials in their discussions with NGO representatives. 
Treaty on European Union. This imposed a severe legislative impediment to the adoption of measures, and particularly binding instruments, which specifically took account of the needs of these groups. The result was, to a large extent, an invisibility of race, disability, age and many other characteristics in Community legislation. Article 13 is significant because it recognises that there is a Community dimension to the various forms of discrimination and formally acknowledges the existence of individuals with the traits that are mentioned in Article 13. It is submitted that this Community recognition of discrimination and of the groups mentioned in Article 13 will in fact have a far broader impact than the adoption of measures on the basis of the Article. The inspiration behind Article 13 is likely to permeate instruments adopted on the basis of other Treaty articles, resulting in the inclusion of clauses specifically providing for equal access or which specifically take account of the needs of (some) of the groups referred to in Article 13. To some extent this process has already begun, as noted below. However its success has been limited, perhaps because of the absence of references to (discrimination against) many of the groups in the present Treaty. Article 13 may therefore open up a realistic possibility of including equal opportunity clauses in Community instruments and of developing general policies which are inclusive of disadvantaged groups.

\section{(i) The inclusion of equal opportunities clauses in community legislation}

In its 1995 Communication on racism, xenophobia and anti-semitism the Commission expressed its intention to ensure the non-discriminatory application of Community legislation by proposing, where appropriate, broad non-discrimination clauses in new Community instruments and when revising or updating existing Community legislation. Consequently the Commission added the following non-discrimination clause to the proposal for a directive on parental leave: 37 'When the Member States adopt the provisions under paragraph 1 they shall prohibit any discrimination based on race, sex, sexual orientation, colour, religion or nationality.' Similar clauses were added by the Commission to the proposal for a directive on part-time work $^{38}$ and the proposed directive to safeguard employee's rights in the event of a transfer of undertakings. ${ }^{39}$ However in each case the proposed clauses were dropped from the final text by the Council.

${ }^{37}$ Com(96) final of 31 January 1996, Article 2(5).

${ }^{38} \operatorname{COM}(97)$ final of 23 July 1997, Article 3. The relevant article in the proposed directive followed Article 13 very closely and referred, in addition to the grounds mentioned in the Parental Leave proposal, to 'ethnic origin, ... beliefs, disability, age'. It did not mention 'colour' which had been referred to in the earlier proposal.

${ }^{39}$ COM 74/0351. 
The adoption of Article 13, and the ratification of the Amsterdam Treaty, may well result in a different approach by the Council. The Commission, in its 1997 Communication establishing 'An Action Plan Against Racism', has already expressed its intention to include non-discrimination clauses in proposals for recitals in measures where appropriate. Article 13, with its clear non-discriminatory objective and reference to many categories of discrimination, may well be a powerful legal argument in favour of the approval of such clauses by the Council.

\section{(ii) Inclusive general policies -'mainstreaming'}

Inclusive general policies, or 'mainstreaming', goes beyond the incorporation of non-discriminatory provisions in Community legislation, and provides for the inclusion of specific measures in general instruments to ensure that certain (minority) groups are able to benefit equally from Community policies. Examples might be a provision included in an Equal Treatment instrument to ensure protection for women who are discriminated against on the grounds that they are lesbian ${ }^{40}$ or a provision in a harmonizing instrument based on Article 95 (ex 100a) to ensure that the minimum standard set to facilitate the free circulation of certain goods in the common market takes account of the needs of disabled consumers. ${ }^{41}$ Such an approach should make less necessary separate instruments which only address e.g. gays and lesbians, people with disabilities or racial minorities.

Prior to the adoption of the Amsterdam Treaty the Commission had already committed itself to pursuing a policy of 'mainstreaming' with regard to many of the categories mentioned in Article 13. However the inclusion of the article could result in a significant up-grading of this approach in certain areas.

The 1997 Action Plan Against Racism provides information on numerous areas where the Commission is already pursuing, or intends to pursue in the future, a 'mainstreaming' approach with regard to racial minorities. These areas include employment; the structural funds; education, training and youth; the information society; justice and home affairs; information, communication, culture, audiovisual and sport; public procurement; and research activities. It is noticeable that many of the 'mainstreaming' measures which have been taken thus far concern so-called 'soft-law'. References are made to funding and

40 This is not the current position. See Case C-249/96 Grant v South West Trains [1998] ICR 449.

41 A Declaration regarding persons with disabilities was adopted at the Amsterdam Intergovernmental Conference stating that: 'The Conference agrees that, in drawing up measures under Article 95 of the Treaty establishing the European Community, the institutions of the Community shall take account of the needs of persons with a disability'. 
exchange programmes such as Socrates and Leonardo $; 42$ action plans; ${ }^{43}$ information campaigns, ${ }^{44}$ and Commission Communications. ${ }^{45}$ This suggests that the absence of a reference to race and ethnic minorities in the Treaty may have hampered the inclusion of references to race in binding instruments, and the development of inclusive policies with regard to ethnic minorities. The adoption of Article 13 may allow for the expansion of measures which take account of ethnic minorities and which counter racial discrimination to include more binding instruments based on various provisions of the Treaty.

In relation to gender the Community institutions have established, inter alia, special committees and structures to ensure that the position of women receives adequate attention when policies are formulated. The Commission has appointed an Advisory Committee on Equal Opportunities for men and women and a Network of Experts on the Implementation of the Equality Law Directives. ${ }^{46}$ Furthermore the Equal Opportunities Working Party of Members of the Commission, chaired by Jacques Santer, examines and monitors the integration of the gender dimension into all relevant policies and programmes. On the recommendation of this Working Party the Commission adopted a Communication on incorporating equal opportunities for women and men into all Community policies and activities. ${ }^{47}$ This approach has been taken forward by the appointment of officials in twenty-nine Commission services and the Commission stated that it intended to introduce gender proofing of legal and other policy proposals in $1998 .{ }^{48}$

These 'mainstreaming' efforts have borne fruit in substantive policy areas. According to Commissioner Flynn: 'The clearest and best example [of gender 'mainstreaming'] is the placing of equal opportunities [for women and men] at the heart of the employment strategy'. ${ }^{49}$ In this respect one of the four pillars included in the 1998 Employment Guidelines, which are the first stage in the

\footnotetext{
42 Education, training and youth-funding for actions designed to improve the educational opportunities of social groups at risk of marginalisation or exclusion; support for transnational projects which involve the exchange of experience between schools with large numbers of pupils from different cultures and linguistic or ethnic backgrounds; equality of access to initial and continuing training.

${ }^{43}$ Information society - action plan on promoting safe use of the Internet (COM(97) 582 of 26 November 1997), including provision to combat the use of the Internet for incitement to racial hatred or racial discrimination.

${ }^{44}$ For example, The European Year Against Racism.

${ }^{45}$ Public procurement, EC directives allow [not require] the exclusion of candidates who breach national social legislation and successful tenderers can be required to comply with social obligations when performing contracts awarded to them.

${ }^{46}$ Commission Decision 82/43/EEC [1982] OJ L20/35.

$47 \mathrm{COM}(96) 97$.

${ }^{48}$ Speech by Commissioner Flynn to the Women's Committee of the European Parliament, 21 January 1998, available at http://europa.eu.int/.

${ }^{49}$ Ibid.
} 
implementation of the new Employment Title included in the Amsterdam Treaty, addressed equal opportunities (primarily with regard to women and men). The ongoing reform of the Structural Funds should also reflect the Commission's commitment to 'mainstreaming' in this area. Arguably more success in 'mainstreaming' has been achieved with regard to gender issues than is the case for race, disability or the other groups referred to in Article 13. This reflects the pre-existing reference in the Treaty to (equal pay for) women, and the numerous provisions of secondary legislation. Correspondingly, the inclusion of Article 13 is less likely to result in drastic increases in efforts to 'mainstream' gender issues than it is for the other categories.

Finally a clear commitment to 'mainstreaming' also exists with regard to disability. The Commission's 1996 Communication on Equality of Opportunity for People with Disabilities notes that an inter-service disability group has been established to raise awareness of disability issues and encourage inter-sectoral cooperation. Areas where 'mainstreaming' are seen as particularly important are research, education, transport, employment and the Information Society. With regard to employment the Commission's 1997 Employment Report included for the first time a special chapter on disability. Furthermore the Luxembourg Employment Guidelines included a brief reference to disability. The Commission has also established an internal group to explore the potential of aspects of the Information Society to promote equal opportunities for people with disabilities and to improve their living and working conditions. 'Mainstreaming' is also seen as very important with regard to the reform of the Structural Funds. However, most of the present initiatives in this field consist of exploratory measures or non-binding instruments, and Article 13 is likely to give a significant legal boost to the Commission's attempts to 'mainstream' disability issues.

The new Article 137(1) EC (ex Article 118 EC) in the Chapter on Social Provisions seems a prime example of a legal basis where the adoption of secondary legislation could be influenced by Article 13, resulting in a 'mainstreaming' approach. Article 137(1) provides for the adoption of directives under the (amended) co-decision procedure in a number of areas including, inter alia, the integration of persons excluded from the labour market.

Even though groups possessing certain of the characteristics mentioned in Article 13, such as racial or ethnic minority status, disability or older people (age), are widely recognised as being disadvantaged in the labour market, and bearing a disproportionate amount of the burden of unemployment, it is unlikely that, in the absence of a specific reference to such groups in the Treaty, binding Community measures would have been adopted to specifically promote the economic integration of these groups. However, it is submitted that the reference to the integration of persons excluded from the labour market, 
combined with references to discrimination (which is a major cause of such exclusion for some groups/individuals) and specific categories of discrimination, could result in the adoption of Community instruments based on Article 137(1) which address the exclusion of e.g. racial minorities, people with disabilities and older people.

\section{The impact of Article 13 on the case law of the European Court of Justice - an expansion of general principles}

The third way in which the inclusion of Article 13 in the new Treaty could impact on Community law is by prompting the European Court of Justice (henceforth: ECJ) to look on the general principle of Community law of equality or non-discrimination in more expansive terms. General principles are developed by the ECJ drawing inspiration from (constitutional) principles common to the laws of the Member States and from international instruments such as the European Convention of Human Rights and Fundamental Freedoms, which the Member States are party to. These principles bind the EU, its institutions and, within the sphere of Community competence, the Member States and individuals.

The ECJ has embraced the general principle of equality or non-discrimination from an early stage in the Community's history. It drew its inspiration not only from the sources mentioned above, but also, significantly, from the $\mathrm{E}(\mathrm{E}) \mathrm{C}$ Treaty. In this respect Articles 6 and $119 \mathrm{E}(\mathrm{E}) \mathrm{C}$ were important, but also, inter alia, Article 40(3) E(E)C which prohibits discrimination in the field of agriculture. In Case 1/72 Frilli $^{50}$ the Court held that equality of treatment 'is one of the fundamental principles of Community law'. Subsequently, in one of the Isoglucose cases the Court held that a Council Regulation which established a levy system on the production of isoglucose 'offend(ed) against the general principle of equality of which the prohibition on discrimination set out in Article 40(3) of the Treaty is a specific expression'. ${ }^{51}$

This general principle has been applied in a number of cases involving discrimination/unequal treatment on the grounds of sex. In Case 20/71 Sabbatini $^{52}$ the Court accepted the claim of a female employee of the European Parliament who had argued that a provision in the Staff Regulations was contrary to the general principle of equality and Article 119. The provision in question denied the allowance given to heads of households to married women

\footnotetext{
50 Case 1/72 Frilli v Belgium [1972] ECR 457 at 466.

51 Joined Cases 103 and 145/77 Royal Scholten-Honig (Holdings) Ltd and Tunnel Refineries Ltd v Intervention Board for Agricultural Produce [1978] ECR 2037 at 2081.

52 Case 20/71 Sabbatini v European Parliament [1972] ECR 345.
} 
unless the husband of the staff member was unable to work because of disability or serious illness. Married men, in contrast, were automatically classified as heads of households.

However, the Court has not applied the general principle of equality to individuals who have suffered discrimination on a ground which is not mentioned in the Treaty. In Case C-249/96 Grant v South-West Trains, ${ }^{53}$ involving discrimination on the grounds of sexual orientation, Ms. Grant, who worked for a train company, had been denied travel concessions for her same-sex partner, whilst an unmarried heterosexual couple would have benefitted from such concessions in the same circumstances. The Court felt unable to follow the Human Rights Committee established under the International Covenant on Civil and Political Rights. It held:

The Covenant is one of the international instruments relating to the protection of human rights which the Court takes account in applying the fundamental principles of Community law.... However, although respect for the fundamental rights which form an integral part of those general principles of law is a condition of the legality of Community acts, those rights cannot in themselves have the effect of extending the scope of the Treaty provisions beyond the competences of the Community (paras 44 and 45).

The incorporation of Article 13 in the EC Treaty will clearly establish the Community's competence to combat discrimination in the named areas, and so open up the possibility for the Court to develop a broader notion of equality/ non-discrimination as a general principle of law. Indeed, Advocate General Elmar, in his Opinion on the Grant case, seemed to have been influenced by Article 13 when he stated:

there is nothing in either the EU Treaty or the EC Treaty to indicate that the rights and duties which result from the EC Treaty, including the right not to be discriminated against on the basis of gender, should not apply to homosexuals, to the handicapped, to persons of a particular ethnic origin or to persons holding particular religious views. Equality before the law is a fundamental principle in every community governed by the rule of law and accordingly in the Community as well. The rights and duties which result from Community law apply to all without discrimination.

However, even if the ECJ did embrace this wider notion of equality/nondiscrimination in a general principle, it is questionable as to whether it would have had an impact on its judgment in the Grant case. The ECJ did not apply Article 119 because it found that there had been no discrimination on the

53 Case C-249/96 Grant v South West Trains Ltd [1998] ICR 449. 
ground of gender. ${ }^{54} \mathrm{~A}$ broader general principle of equality, covering inter alia discrimination on the grounds of sexuality, could not have had the effect of extending Article 119 to cover other grounds of discrimination not already mentioned in the Article.

A broad general principle of equality/non-discrimination also finds its basis in principles common to the laws of the Member States and in international instruments which the Member States are party to. Numerous national constitutions, including the Spanish (Article 14), German (Article 3) and Dutch constitutions (Article 1), contain a broad equality clause. Other national constitutions containing similar provisions include the Italian (Article 3), Portuguese (Article 9) and Finnish (Section 5) constitutions.

Inspiration for a general equality/non-discrimination principle can also be found in international agreements which the Member States are party to. The European Convention for the Protection of Human Rights and Fundamental Freedoms, to which the ECJ has often referred, contains a non-discrimination clause in Article 14, albeit that this clause only covers the rights and freedoms contained in the Convention itself. A similar reference is found in the preamble to the European Social Charter.

The International Covenant on Civil and Political Rights is perhaps most strident with regard to discrimination:

All persons are equal before the law and are entitled without any discrimination to the equal protection of the law. In this respect, the law shall prohibit any discrimination and guarantee to all persons equal and effective protection against discrimination on any ground such as race, colour, sex, language, religion, political or other opinion, national or social origin, property, birth or other status (Article 26).

In addition to these general instruments to which the Member States of the European Union are party, there are also a number of important international conventions, such as the Convention on the Elimination of all Forms of Racial Discrimination and the Convention on the Elimination of Discrimination Against Women, which address specific areas, which the Member States are party to.

The incorporation of the general non-discrimination clause in Article 13, with its reference to a number of specific grounds of discrimination which have thus far not been referred to in the Treaty, combined with the existing provisions in numerous Member State constitutions and international instruments, may therefore open up the way for an expansion by the ECJ of the general principle of

\footnotetext{
${ }^{54}$ Of course, it is debatable as to whether this conclusion was correct. The Court compared Ms Grant (and her partner) to a homosexual male and his partner, and found that both a man and woman in this situation were treated equally. If the Court had found that the relevant comparator was an unmarried heterosexual male and his female partner it would have been possible to reach a finding that Ms Grant had been the victim of gender discrimination (rather than discrimination on the grounds of sexuality).
} 
equality/non-discrimination. Whilst failure to comply with a general principle of Community law is not an independent cause of action before the Court, it is a matter which is regularly addressed by the ECJ in the cases before it. However, a general principle of Community law cannot extend the scope of a provision of Community law to e.g. groups not mentioned in that provision, and this will restrict the impact of a broader general principle. It is submitted that such a general principle will only become significant in ECJ case law if Article 13 leads to the developments referred to earlier in this paper-namely the adoption of measures on the basis of the Article itself, and impacting on instruments adopted on the basis of other provisions of the Treaty through the promotion of 'mainstreaming' and non-discrimination clauses. In such a scenario the general principle would have provisions of Community law to which it could be 'attached'.

A further limitation is that general principles of Community law do not have horizontal direct effect, ${ }^{55}$ so the principle of equality could not impose direct duties on private parties -instead its effect will again be dependent on the possibility to interpret legislation which imposes obligations on private parties in the light of the general principle.

One area in which an expanded equality/non-discrimination principle could have some effect in the short-term is the interpretation of Article 7 of the Directive on Equal Treatment for Men and Women in Matters of Social Security, ${ }^{56}$ which currently exempts pensionable age for the purpose of granting retirement pensions and other benefits from its scope. A broader general principle which specifically takes account of discrimination on the grounds of age could result in the Court adopting a very restrictive interpretation of this provision. Such an approach could impact on a case such as Secretary of State for Social Security v Rose Graham and Others ${ }^{57}$ in which the Court held that it was permissable to limit eligibility for invalidity allowance to people who were under a certain age ${ }^{58}$ (which was under the official retirement age) when they first became incapacitated for work.

\section{CONCLUSION}

An initial examination of Article 13, with its somewhat confusing terminology, requirement of unanimity in the Council, and absence of direct effect, may give

55 This is also generally true of equality provisions in national constitutions.

56 OJ [1979] L6/24.

57 Case C-92/94, [1995] ECR I-2521.

58 The relevant ages were 55 for women (official retirement age in the Member State in question was 60 ) and 60 for men (official retirement age was 65). 
the impression that it amounts to little more than fine words, and that meaningful changes are unlikely to occur as a result of its inclusion in the Treaty. However, the above analysis has revealed that Article 13, and the thinking behind it, may indeed impact on the Community (and Member States) legal order. The Commission, backed no doubt by the Parliament, seems to be determined to produce legislative proposals the short-run. Meanwhile, Article 13 is likely to also exert more subtle influences, promoting the inclusion of equal opportunities clauses in instruments adopted on the basis of other Treaty articles, and the development of inclusive polices through such instruments. Furthermore, an expansion of the general principle of equality, and the application of such a principle by the ECJ in cases involving the instruments referred to (or perhaps better 'predicted') above could also contribute to a new climate within the Community legal order. Article 13 may not have satisfied those calling for a greater protection of fundamental social rights within the Treaties prior to the IGC, but it is perhaps more valuable than it appears at first sight. 
